\title{
Over de verhouding tussen overheid, marktwerking en privatisering. Een economische meta-analyse
}

Citation for published version (APA):

van Mierlo, J. G. A. (2001). Over de verhouding tussen overheid, marktwerking en privatisering. Een economische meta-analyse. METEOR, Maastricht University School of Business and Economics. METEOR Research Memorandum No. 014 https://doi.org/10.26481/umamet.2001014

Document status and date:

Published: 01/01/2001

DOI:

10.26481/umamet.2001014

Document Version:

Publisher's PDF, also known as Version of record

\section{Please check the document version of this publication:}

- A submitted manuscript is the version of the article upon submission and before peer-review. There can be important differences between the submitted version and the official published version of record. People interested in the research are advised to contact the author for the final version of the publication, or visit the DOI to the publisher's website.

- The final author version and the galley proof are versions of the publication after peer review.

- The final published version features the final layout of the paper including the volume, issue and page numbers.

Link to publication

\footnotetext{
General rights rights.

- You may freely distribute the URL identifying the publication in the public portal. please follow below link for the End User Agreement:

www.umlib.nl/taverne-license

Take down policy

If you believe that this document breaches copyright please contact us at:

repository@maastrichtuniversity.nl

providing details and we will investigate your claim.
}

Copyright and moral rights for the publications made accessible in the public portal are retained by the authors and/or other copyright owners and it is a condition of accessing publications that users recognise and abide by the legal requirements associated with these

- Users may download and print one copy of any publication from the public portal for the purpose of private study or research.

- You may not further distribute the material or use it for any profit-making activity or commercial gain

If the publication is distributed under the terms of Article $25 \mathrm{fa}$ of the Dutch Copyright Act, indicated by the "Taverne" license above, 


\title{
Over de verhouding tussen overheid, marktwerking en privatisering. Een economische meta-analyse
}

Eerste versie: 6 juli 2001

Tweede versie: 23 augustus 2001

\author{
Prof Dr J.G.A. van Mierlo \\ Hoogleraar Openbare Financiën \\ E-mail: h.vanmierlo@algec.unimaas.nl
}

Faculteit der Economische Wetenschappen en Bedrijfskunde

Universiteit Maastricht

Postbus 616

6200 MD Maastricht, Nederland

Tel ++31 $43883641 / 3636$

Fax ++31433884878 


\title{
Samenvatting/summary
}

\author{
J.G.A. van Mierlo* \\ Over de verhouding tussen overheid, marktwerking en privatisering. \\ Een economische meta-analyse
}

Over de verhouding tussen overheid en markt wordt steeds vaker de grootst mogelijk onzin verkondigd. Dat gebeurt niet alleen in de universitaire (economische) wetenschap, maar vooral ook in de politieke wereld van de beleidsmakers. Dat heeft fatale gevolgen voor ons wetenschappelijk denken over marktwerking en overheidsinterventie en voor privatiseringsoperaties in de beleidspraktijk. In dit artikel wordt met een behulp van een zogeheten 'economische meta-analyse' de verhouding tussen overheid, marktwerking en privatisering onderzocht, met de bedoeling om aan deze begripsverwarring een einde te maken. Op basis van deze meta-analyse wordt een instrumentele privatiseringstheorie ontwikkeld, waarmee tenslotte een vingeroefening op de NS wordt beproefd.

* Prof Dr J.G.A. van Mierlo is hoogleraar Openbare Financiën aan de Faculteit der Economische Wetenschappen en Bedrijfskunde van de Universiteit Maastricht. Hij is tevens lid van de Redactieadviesraad van Bestuurswetenschappen. Hij dankt de redactie van dit tijdschrift, evenals dr G. Woltjer, universitair docent Micro-Economie aan de Universiteit Maastricht, voor hun nuttig commentaar bij de eerste versie van dit artikel.

\section{J.G.A. van Mierlo*}

On the relation between government, market and privatisation.

An economic meta-analysis

On the relation between government and market the greatest nonsense is increasingly published. This unfortunately does not only occur in economic science, but also in the political world of policy makers, with fatal consequences for our scientific thinking about market provision and government intervention and for privatisation operations in policy practice. In this article an 'economic meta-analysis' is applied to investigate the relation between government, market and privatisation, in order to solve the intellectual confusion about these concepts. An instrumental privatisation theory is developed on basis of this metaanalysis. Finally, a finger exercise is applied to the case of the NS.

* Prof Dr J.G.A. van Mierlo is professor of Public Finance in the Faculty of Economics and Business Administration of the Universiteit Maastricht. He is also a member of the editorial advice board of Bestuurswetenschappen. He expresses his acknowledgements to the Editors of this journal and to Dr G. Woltjer, assistant professor of Micro-Economics at the Universiteit Maastricht, for their valuable comments on the first draft of this article. 


\section{Inhoudsopgave}

1. Markt en overheid 4

2. Doeleinden en instrumenten van economische politiek 5

3. Marktwerking en marktfalen $\quad 5$

4. Overheidsingrijpen en overheidsfalen 6

5. Bestrijding van overheidsfalen door concurrentie 6

6. Toezichthouders en netwerkbesturing 9

7. Een algemeen plan van aanpak van privatisering 10

8. Een vingeroefening met de NS 12

8.1 De hypotheek van het verleden 12

8.2 Gebrekkige privatiseringsaanpak 13

8.3 Wat moet er nu worden gedaan? 14

9. Bij wijze van conclusie 14

$\begin{array}{ll}\text { Gebruikte literatuur } & 15\end{array}$ 


\section{Markt en Overheid}

Over de verhouding tussen overheid en markt wordt steeds vaker de grootst mogelijke onzin verkondigd, niet alleen in de (economische) wetenschap maar vooral ook in de politieke wereld van de beleidsmakers. Dat is des te tragischer naarmate er meer privatiserings- en marktwerkingoperaties worden ondernomen en naarmate daarin steeds weer problemen optreden, die de tegenstanders van marktwerking (soms echter maar vaker vermeende!) argumenten in handen spelen om een en ander terug te draaien. Of het nu gaat om marktwerking in het onderwijs, de sociale zekerheid of de gezondheidszorg, of het nu gaat om privatisering van de spoorwegen, gas, water en elektriciteit of om de verzelfstandiging van de Informatiebeheergroep en de Immigratie- en Naturalisatiedienst, en of het nu gaat om UMTS- en andere veilingen, cliëntgebonden budgetten of vouchersystemen.

De hamvraag is steeds hoe wij publieke voorzieningen efficiënter kunnen laten werken en hoe wij de zeggenschap erover weer terug kunnen geven aan de burgers, voor wie zij toch zijn bedoeld. Dat is ook waar het om hoort te draaien bij het borgen van het publieke belang (WRR, 2000). Voor beide doelstellingen is het nodig, dat verzelfstandigde instellingen en geprivatiseerde bedrijven in een competitieve omgeving opereren. Dat geeft de burgers immers echte keuzevrijheid, maar dat wordt in het privatiseringsdebat helaas te weinig begrepen. In de genoemde studie "snapt ook de WRR er helemaal niets van" (letterlijk citaat van de macro-econoom Sweder van Wijnbergen in NRC van 3 juni 2000 bij het bovengenoemde WRR-rapport 'Het Borgen van Publiek Belang', dat is geschreven door de socioloog W. Derksen, hoogleraar Bestuurskunde in Rotterdam). Het probleem is immers niet zozeer dat er niet zou worden nagedacht over de vraag hoe het publiek belang te waarborgen, maar dat er niet wordt nagedacht over wat dat publiek belang nu eigenlijk ís. Er is echter geen garantie dat economen het beter doen, getuige de vinnige discussie tussen Kalshoven (2001a en 2001b) en Kalma (2001a en 2001b) over 'overheid en markt'. Ook de actievoerders tegen 'de uitverkoop van de beschaving' (Klamer, toch ook econoom maar door Jan Blokker een 'economisch dwaallicht' (sic!) genoemd, e.a., 2001) maken de fout om privatiseringsproblemen te wijten aan te veel markt, in plaats van aan te weinig markt of aan een verkeerde markt.

Probleem is dat de werkelijkheid al lang niet meer kan worden gevangen met de modeleenvoud van slechts twee institutionele arrangementen, overheid óf markt. Degenen die dat wel mogelijk achten of er zelfs naar terug verlangen, zijn ongeneeslijke romantici. Zij willen terug naar een wereld die nooit heeft bestaan, hooguit alleen in de boekjes en voor wie die goed leest zelfs daarin niet. Daar komt nog bij dat zelfs in de economische wetenschap geen uitgebalanceerde privatiseringstheorie is ontwikkeld, die handreikingen kan bieden voor het privatiseringsbeleid in de praktijk. Dat is ook opgemerkt door de al genoemde Sweder van Wijnbergen in zijn afscheidscolumn in het NRC bij zijn verstrek als topambtenaar bij Economische Zaken (Van Wijnbergen, 2000). Niettemin zijn er wel bouwstenen voor zo'n instrumentele theorie voorhanden, zoals diezelfde Van Wijnbergen met zijn analyseschema voor privatisering van netwerksectoren eerder in het NRC heeft laten zien (zie Alberts en Berkhout, 1999). Ik om op dit schema hieronder nog terug.

Laten wij de bouwstenen voor een instrumentele privatiseringstheorie daarom eens op een rij zetten. In paragraaf 2 wordt ingegaan op het onderscheid tussen doeleinden en instrumenten van economische politiek. Marktwerking en marktfalen komt aan de orde in de derde paragraaf. Paragraaf 4 is gewijd aan overheidsingrijpen en overheidsfalen. Bestrijding van overheidsfalen door vormen van concurrentie wordt behandeld in paragraaf 5. Vervolgens wordt in de zesde paragraaf aandacht besteed aan de noodzaak van toezichthouders en netwerkbesturing. Een algemeen plan van aanpak van privatisering wordt ontwikkeld in paragraaf 7 . In paragraaf 8 wordt een vingeroefening met de NS gepresenteerd. Tenslotte worden in paragraaf 9 enkele conclusies geformuleerd. 


\section{Doeleinden en instrumenten van economische politiek}

Nederlands beroemdste welvaartseconoom Pieter Hennipman zei het al in 1945 in zijn proefschrift 'Economisch Motief en Economisch Principe': er zijn geen economische doeleinden (ofwel: géén economisch motief), er zijn alleen economische middelen die schaars en alternatief aanwendbaar zijn (ofwel: wél economisch principe). Zijn leerlingen en míjn leermeesters Hans van den Doel (Van den Doel en Van Velthoven, 1998) en Dik Wolfson (Wolfson, 1978; 1988 en 2001) zeiden het hem als volgt na. Doeleinden en instrumenten van economische politiek zijn twee geheel verschillende zaken die analytisch-wetenschapplijk uit elkaar moeten worden gehaald, maar ideologisch-beleidsmatig helaas al te vaak met elkaar worden verward. Maatschappelijke doelstellingen kunnen links of rechts zijn, liberaal of socialistisch, conservatief of progressief, maar altijd politiek bepaald. In het politieke proces worden zij democratisch vastgesteld en kunnen zij in een zogeheten 'maatschappelijke welvaartsfunctie' worden uitgedrukt. De daarin opgenomen parameters geven bijvoorbeeld de ruilvoet weer tussen de doelstellingen van allocatieve efficiëntie (maximalisatie van de collectieve welvaart) en van verdelende rechtvaardigheid (verdeling van de collectieve welvaart), die door politieke partijen en in het overheidsbeleid feitelijk wordt gehanteerd.

Overheidsarrangementen en marktmechanismen, met alles wat daartussenin zit en in alle mogelijke combinaties, zijn vervolgens de technische instrumenten van economische politiek die uitsluitend moeten worden beoordeeld op hun consequenties voor de effectiviteit (werkt het?) en efficiëntie (tegen de minste kosten?), waarmee de doelstellingen van economische politiek worden gerealiseerd. Niet eventuele ideologische voorkeuren voor markt versus overheid dienen de keuze voor het optimale institutionele arrangement te bepalen, maar hun technische bijdrage aan het bereiken van de maatschappelijke welvaartsfunctie. In deze benadering is dus geen plaats voor blind marktfetisjisme en evenmin voor eenzijdig étatisme. Liberalen zouden alleen van de markt moeten houden voor zover die bijdraagt aan de maximalisatie van de maatschappelijke welvaartsfunctie. Socialisten zouden alleen van de overheid moeten houden voor zover die dat hetzelfde doet. Niet minder maar ook niet meer! Dit is ook het uitgangspunt van mijn oratie over het falen van overheidsbeleid (Van Mierlo, 2000).

\section{Marktwerking en marktfalen}

Vervolgens hebben markteconomen aangetoond, dat de markt kan leiden tot een optimale allocatieve efficiëntie, waardoor de collectieve welvaart wordt gemaximaliseerd. Dat is het geval als de markt aan bepaalde technische voorwaarden voldoet. Die marktvorm betreft het model van volkomen en vrije mededinging, ook wel het 'VVM-model' genoemd. Voorwaarden zijn onder meer een gegeven prijs; geen marktmacht van vragers of aanbieders en dus voldoende vragers en aanbieders; volledige informatie en dus markttransparantie; homogene consumentenvoorkeuren; geen schaalvoordelen, externe effecten of collectieve goederen. Als aan al die voorwaarden wordt voldaan kan wiskundig worden bewezen, dat op die manier het bekende Pareto-optimum wordt bereikt (met behulp van de twee zogeheten 'fundamentele welvaartstheoremata', zie bijvoorbeeld de veelgebruikte handboeken Economie van de publieke sector van Connolly en Munro, 1999; Stiglitz, 2000).

Als aan die voorwaarden niet wordt voldaan, wordt gesproken van marktfalen. Te weinig vragers of aanbieders leidt tot marktmacht, waardoor prijzen niet meer gegeven zijn maar kunnen worden gezet. Onvolledige informatie leidt tot een asymmetrische markt en zet vragers of aanbieders op achterstand. Heterogene consumentenvoorkeuren maken productdifferentiatie, marktsegmentatie en monopolievorming mogelijk. Schaalvoordelen leiden tot natuurlijke monopolies en externe effecten tot prijsvertekening, en beide dus tot verkeerde economische 
beslissingen. Collectieve goederen leiden via het 'prisoner's dilemma' en 'free rider-ship' tot suboptimale verschaffing ervan. De economische theorie van het marktfalen is ontwikkeld in de jaren zestig en vormt bijvoorbeeld ook de grondslag van het bekende boekje van de econoom E.J. Mishan over 'The Costs of Economic Growth' uit 1968, waarin voor het eerst een complete welvaartstheoretische analyse van het milieuvraagstuk werd gepresenteerd.

\section{Overheidsingrijpen en overheidsfalen}

Al deze categorieën van marktfalen nopen op een of andere manier tot overheidsingrijpen, maar daarmee is nog niets gezegd over de manier waaróp de overheid moet ingrijpen. Marktwerking en het tegengaan van marktfalen vormen tezamen het fundament van de moderne Nederlandse en Europese mededingingspolitiek. Daarin wordt het ideaaltypische VVM-model vertaald in reaaltypische concepten van 'workable competition' en 'contestable markets', ofwel 'werkbare mededinging' en 'betwistbare markten'. Als de marktmacht van ondernemingen te groot wordt faalt de markt en dient mededingingsbeleid te worden gevoerd. De markt faalt ook als de maatschappelijke kosten van bijvoorbeeld vervuiling niet in de prijzen van produkten of diensten worden verwerkt en dan zijn milieubelastingen nodig. De markt faalt wederom als maatschappelijke baten niet in de prijzen worden verwerkt. Dan zijn subsidies nodig, bijvoorbeeld voor onderwijs en voor onderzoek en ontwikkeling. De markt faalt tenslotte als relevante informatie ongelijk over marktpartijen is verdeeld. Bij ziektekostenverzekeringen kan dat worden verholpen door een acceptatieplicht. Op deze manier ontvouwt zich een breed scala van overheidsinstrumenten.

Dit is evenwel slechts de helft van het verhaal. In de organisatie van de publieke sector kennen wij inmiddels het pendant van marktfalen: overheidsfalen. Marktfalen maakt het noodzakelijk dat de overheid ingrijpt in het economisch proces, maar de vraag hoe de overheid dat moet doen leidt tot een nieuwe debatronde. Het grote probleem van een overheid die sectoren van de marktsector overneemt om redenen van marktfalen - Kalshoven (2000a) noemt hierbij als voorbeelden elektriciteit, openbaar vervoer, telefonie, onderwijs en gezondheidszorg - is, dat elke prikkel ontbreekt om fatsoenlijke produkten en diensten te leveren. Dat inzicht heeft in de jaren tachtig geleid tot de formulering van de economische theorie van het overheidsfalen.

Een van de grondleggers ervan, de econoom Ch. Wolfe (1993), onderscheidt vier categorieën van overheidsfalen: organisationele doelverschuiving (organisaties ontwikkelen gaandeweg andere doelstellingen dan waarvoor zij oorspronkelijk zijn opgericht), bureaucratische (X-)inefficiënties (kosten van verspilling en verkeerde bedrijfsvoering), nieuwe externe effecten van overheidsingrijpen (waardoor anderen dan de doelgroepen worden getroffen) en nieuwe ongelijkheden (verbonden aan privileges, machtsposities en middelenverdeling in de publieke sector). Deze vier categorieën van overheidsfalen worden veroorzaakt door de specifieke vraag/aanbod-structuur in de publieke sector. Daarin ontbreekt immers een zogenoemd 'rationeel prijssysteem', waardoor vraag en aanbod in evenwicht worden gebracht en waardoor tekorten of overschotten worden geruimd. In de publieke sector is zo'n evenwichtsbevorderend mechanisme afwezig. Uiteindelijk kunnen de kosten van zulk overheidsfalen van overheidsinterventie daardoor groter worden dan de kosten van het oorspronkelijke marktfalen waarop het overheidsingrijpen was gericht. Ofwel: het middel kan erger zijn dan de kwaal.

\section{Bestrijding van overheidsfalen door concurrentie}

Als dat zo is zouden bij uitstek socialisten, maar niet alleen zij (!), vooral wakker moeten liggen van de vraag: hoe kan zulk overheidsfalen worden beperkt? Het antwoord op die vraag luidt voor 
elke sector anders. Er zijn geen algemeen en eeuwig geldige antwoorden op deze vraag, want die hangen af van de specifieke sector en bedrijfstak in kwestie. Alle antwoorden hebben echter wel gemeen, dat gezocht wordt naar een manier om concurrentie in te bouwen.

Concurrentie kan plaats hebben op een echte markt, maar dat hoeft niet persé. Ook binnen de publieke sector en in de derde, non profit-sector kunnen concurrentiemechanismen worden ingebouwd (zie voor een variëteit van concurrentiemechanismen in de publieke sector bijvoorbeeld Walsh, 1995). In dat geval wordt gesproken van een 'gecontroleerd marktmechanisme'. Scholen kunnen best met elkaar concurreren om de klanten, evenals ziekenhuizen en woningcorporaties, zonder dat daar markten met echte ruiltransacties ('quid pro quo', zegt de econoom) aan te pas komen. Zulke markten worden 'quasi-markten' genoemd (naar LeGrandt en Bartlett, 1993). Soms is volledig privatisering naar een echte, reeds bestaande of nieuw te creëren markt verstandig, zoals bij de telefonie (KPN). Vaak echter ook niet als dat leidt tot private monopolies die slecht worden gereguleerd, zoals de NS.

Netwerksectoren, en daar hebben wij er nogal wat van, vormen een ernstige complicatie. Openbaar vervoer en nutsbedrijven zijn zogeheten 'netwerksectoren', waarin het gebruik van de netwerkinfrastructuur extreem hoge vaste kosten en verwaarloosbare variabele kosten (en dus marginale kosten van nagenoeg nul) met zich meebrengt. Dat leidt tot extreme schaalvoordelen en dus tot 'natuurlijke monopolies': de optimale bedrijfsomvang is uiteindelijk gelijk aan de gehele bedrijfstakomvang. Nieuwkomers zullen doorgaans niet een nieuw concurrerend netwerk kunnen aanleggen, maar moeten toegang zien te krijgen tot het bestaande netwerk. Het zittende bedrijf dat controle over dat netwerk heeft, krijgt zo een machtspositie door 'sunk costs', ofwel 'verzonken kosten', die door het zittende bedrijf reeds zijn gemaakt en afgeschreven maar door de nieuwkomer nog moeten worden gemaakt. Dat levert een formidabele toetredingsbelemmering op waarmee concurrentie onmogelijk kan worden gemaakt.

In dat geval moet de verticale integratie tussen het beheer van de netwerkinfrastructuur en het gebruik ervan uit elkaar worden gehaald. Daarmee wordt het ene probleem, de monopolide identiteit tussen infrastructuur-eigenaar en -gebruiker, opgelost. Voor de NS betekent dat bijvoorbeeld een verticale splitsing tussen het netwerk (Railned) en het gebruik (NS-Reizigers). Vervolgens kan het gebruik ervan worden uitbesteed aan meerdere gebruikers van verschillende baanvakken. Dat is concurrentie om het spoor. Ook kan worden uitbesteed aan meerdere gebruikers van dezelfde baanvakken. Dat is concurrentie op het spoor. Bij concurrentie op het spoor gaan schaalvoordelen verloren, zoals de toestand bij de Britse spoorwegen laat zien, omdat het hele netwerk wordt opgesplitst in kleinere eenheden. Bij concurrentie om het spoor is dat ook het geval als slechts een gedeelte van het netwerk daaraan wordt onderworpen, maar er zijn dan ook nog eens zogenoemde 'agency-kosten' in het geding (uitbesteding vergt permanente monitoringkosten en recursieve transactiekosten), zoals de situatie bij Noordned aantoont. Het organiseren van concurrentie brengt dus ook altijd nieuwe organisatiekosten met zich mee. Bovendien treedt er een ander probleem op bij het opheffen van verticale integratie: het optimaliseren van het gebruik van de infrastructuur ten opzichte van de beschikbare capaciteit. Dat vergt grote kwaliteiten van de netwerkmanager, zo leert de praktijk van Railned in geval van de NS.

Het privatiseringstraject is in het geval van netwerksectoren dus gecompliceerd, maar daarvoor kan het analyseschema van Van Wijnbergen heel goed worden gebruikt. De redenering gaat als volgt. Uiteindelijk draait alles om het karakter van de netwerken die de infrastructuur vormen: de gaspijpen, de telefoondraden of de hoogspanningsleidingen. Is er concurrentie op het net mogelijk? Zo niet, dan kan marktwerking alleen door concessies voor monopolies te vergeven. Zo ja, dan hangt de vorm af van de vraag hoe je het netwerk (het telefoonnet of het spoorwegnet) van de aanbieder (KPN of NS) kunt scheiden. Dat betekent een einde aan de verticale integratie van netwerk en gebruikers. Bovendien hangt de vorm af van de vraag hoe eenvoudig de toegang tot het netwerk is. 
Het analyseschema heeft de vorm van een stroomdiagram en ziet er als volgt uit (zie tabel 1):

\section{Tabel 1: Analyseschema Van Wijnbergen voor privatisering van netwerksectoren}

Startvraag: is er concurrentie tussen netten?

Antwoord ja: dan is er geen probleem (voorbeeld: telefoon versus internet).

Antwoord nee: dan door naar vervolgvraag 1 .

Vervolgvraag 1: is er concurrentie op het net mogelijk?

Antwoord nee: dan concurrentie om het net organiseren (voorbeeld: NS-kernnet); gevolgen: langere licentieperiode en strengere regulering

Antwoord ja: dan door naar vervolgvraag 2.

Vervolgvraag 2: is scheiding van netwerk en dienstverlener mogelijk?

Antwoord nee: dan is er een moeilijk reguleringsprobleem (voorbeeld: KPN en OPTA).

Antwoord ja: dan door naar vervolgvraag 3 .

Vervolgvraag 3: is toegang tot netwerk eenvoudig en transparant?

Antwoord nee: dan zijn juridisch afzonderlijke ondernemingen noodzakelijk.

Antwoord ja: administratieve scheiding binnen onderneming is voldoende.

Met dit analyseschema kan in elk geval de technische problematiek van netwerksectoren worden aangepakt. Maar er zijn ook andere, niet-netwerkgebonden sectoren in de publieke sector. In geval van onderwijs en gezondheidszorg kan binnen de publieke sector en binnen de non profit-sector worden geconcurreerd met behulp van vouchersystemen, cliëntgebonden budgetten (de zogeheten 'rugzakjes met geld' waarvan de besteding niet vrij maar gebonden is), of zelfs gedeeltelijk of volledig vrij besteedbare vraagsubsidiëring. Met al deze instrumenten wordt niet langer het aanbod gesubsidieerd, maar de vraag gefaciliteerd. Zo worden publieke dienstverleners gedwongen om 'maatschappelijke ondernemingen' (zie De Waal, 2000) te worden, die hun diensten moeten afzetten op een quasi-markt van vragers en daarmee hun inkomsten moeten verwerven.

Daartoe is wel vereist dat de markt transparant is: de gebruikers moeten kunnen beschikken over relevante en betrouwbare aanbodinformatie om hun keuze te kunnen maken. Daarom is openbaarheid van 'gewaarmerkte' kengetallen zo belangrijk, zie de discussie over de kwaliteit van scholen voor voortgezet onderwijs naar aanleiding van de Trouw-enquete enkele jaar geleden. Daarmee zijn aanbieders ook niet langer afhankelijk van hun voormalige sponsor, de subsidiërende overheid, maar worden zij gedwongen tot meer klant- en marktgerichtheid. Op die manier wordt de zeggenschap over deze voorzieningen weer teruggegeven aan de klanten. Bovendien worden er zo meer efficiëntieprikkels ingebouwd. 


\section{Toezichthouders en netwerkbesturing}

Of wij nu het privatiseringstraject helemaal tot aan het einde toe door-exerceren (echt marktbedrijf onder concurrentie), of slechts tot halverwege (interne of externe verzelfstandiging tot agentschappen of zelfstandige bestuursorganen): in alle gevallen is een toezichthoudende instantie nodig tussen het ministerie (de overheid als beleidsbepaler en als opdrachtgever) en de uitvoerende instellingen (de echte of quasi-markt). Dat kan in algemene sectoren de Nederlandse Mededingingsauthoriteit (NMa) zijn, maar in specifieke sectoren ook specifieke toezichthouders, afhankelijk van de sectorspecificiteit van de vigerende technische en marktproblemen. Specifieke toezichthouders kennen wij van oudsher in de financiële wereld (De Nederlandsche Bank, de Pensioen- en Verzekeringskamer en recent de Stichting Toezicht Effectenverkeer STE, die ook nauw met elkaar samenwerken). Verder zijn er de Waarderingskamer voor de WOZ, de DTe voor de elektriciteitssector (nog onderdeel van de NMa) en de OPTA voor de telecommunicatie. Tenslotte kennen wij de klassieke Inspecties voor het onderwijs, de gezondheidszorg, de volkshuisvesting en de ruimtelijke ordening, het milieu en de landbouw (AID).

De algemeen-bestuurlijke trend is dat beleid en uitvoering steeds meer uit elkaar worden getrokken. Privatisering past in die trend en dan worden toezichthouders steeds belangrijker. De beleidsmakers bepalen nog steeds de spelregels, maar de toepassing ervan wordt in handen gelegd van toezichthouders op afstand van het beleid. Daarmee wordt een noodzakelijke buffer gelegd tussen beleid en uitvoering en wordt de politiek beschermd tegen de verleiding, om rechtstreeks in te grijpen in individuele gevallen en weer regel te maken van uitzonderingssituaties. De toezichthouders dienen een duidelijke algemene takopdracht van de overheid mee te krijgen. Bovendien moeten zij als nieuwe 'marktmeesters' over de nodige economische en juridische expertise te beschikken of die te ontwikkelen. Voor dit laatste doel hebben de gezamenlijke toezichthouders pas geleden een heus opleidingsinstituut opgericht, de 'Inspectieacademie'. De broodnodige expertise wordt bovendien door 'trial and error' in een leerproces opgebouwd tijdens het proces van toezicht houden zelf. De (geenszins rituele!) dans tussen de OPTA en voormalig monopolist KPN-Telecom leert ons, dat beide partijen in zo'n proces vooral van elkaar kunnen leren.

Tenslotte blijft er een groot besturingsprobleem over. In zijn oratie wijst Camps (2001) er nog eens op dat wij met de verdere ontwikkeling van meer marktwerking en privatisering (zoals vervat in de MDWK-operatie Marktwerking, Deregulering en Wetgevingskwaliteit) groeien in de richting van complexe en horizontaal georganiseerde beleidsnetwerken (en dat is iets anders dan de infrastructuurnetwerken van hierboven!) van publiek-private relaties. Succes of falen van overheidsbeleid in een beleidsnetwerksituatie kan dan niet langer worden toegeschreven aan één enkele beleidsactor in dat netwerk, maar is het resultaat van het totaalfunctioneren van dat netwerk.

Dan groeit ook de behoefte aan een eindverantwoordelijke netwerkregisseur. Hier ligt een nieuwe en andere taak voor de overheid in plaats van die van de klassieke publieke dienstverlener. De overheid is niet langer verantwoordelijk voor de inhoud van het resultaat, maar uitsluitend voor het feit dat er een ordentelijk resultaat tot stand komt. In plaats van voor de dienstverlening zelf draagt de overheid verantwoordelijkheid voor een ordentelijke organisatie van het dienstverleningsnetwerk. Eerder heb ik dat in mijn oratie (2000) in navolging van In 't Veld de rol van de 'overheid als procesarchitect' genoemd, die verantwoordelijk wordt voor de 'procesarchitectuur' van het netwerk. Dat vergt andere sturingsrelaties (tweezijdige en horizontale economische transacties in plaats van eenzijdige en verticale en juridische bevoegdheden) en ook andere verantwoordelijkheidsmechanismen (afspraken vooraf, regelmatige inspectie tussentijds, verantwoording achteraf). 


\section{Een algemeen plan van aanpak van privatisering}

Van Wijnbergen heeft zijn analyseschema speciaal ontwikkeld voor infrastructurele netwerksectoren. Laat ik op basis van de wetenschappelijke literatuur een poging doen tot een meer algemeen plan van aanpak van privatisering. Dat plan van aanpak heeft meer het karakter van een open einde-procesbenadering dan van een gesloten programmatische blauwdruk. Het analyseschema van Van Wijnbergen zou daarin moeten worden ondergebracht. Laten wij verder uitgaan van de situatie, dat de activiteiten in kwestie zijn ondergebracht in de publieke sector en dat marktwerking en privatisering worden overwogen. Het plan van aanpak kan dan in twee ronden worden gesplitst. In de eerste ronde wordt een verantwoorde keuze van het einddoel, de privatiseringsvariant, gemaakt. In de tweede ronde wordt een verantwoorde weg daar naartoe gebaand.

De eerste ronde betreft het antwoord op de vraag: welke variant van privatisering moet worden gekozen? Daartoe moeten de volgende specifieke vragen worden beantwoord (zie tabel 2):

\section{Tabel 2. Analyseschema ter bepaling van privatiseringsvariant}

1. Welke argumenten van marktfalen hebben geleid tot overheidsingrijpen met betrekking tot betrokken voorziening, waarom is vervolgens gekozen voor welke vorm van overheidsingrijpen en waarom voor uiteindelijke opname van die voorziening in de publieke sector?

2. Door welke vormen van overheidsfalen wordt de huidige voorziening getroffen en kunnen wij de economische (= alternatieve) kosten daarvan ook kwantificeren?

3. Welke efficiëntiewinsten kunnen worden behaald met welke vorm van privatisering (uitbesteding, interne of externe verzelfstandiging, mengvormen daarvan, volledige privatisering)?

4. Welke nieuwe kosten van marktfalen en welke nieuwe transactiekosten zijn er verbonden aan elk van deze privatiseringsvarianten en kunnen wij de uiteindelijke saldo-effecten (met verdiscontering van eventuele efficiëntiewinsten) bepalen?

5. Welke privatiseringsvariant is uiteindelijk de beste en moet daarom worden gekozen, onder de gegeven technische kenmerken aan de aanbodzijde en de gegeven politiek-culturele voorkeuren aan de vraagzijde van de betrokken voorziening?

Bij de vragen drie tot en met vijf dient te worden onderscheiden tussen effecten op de korte termijn en die op de lange termijn. Door aanpassingsvertragingen zullen veel effecten pas op langere termijn zichtbaar worden. Ook zullen veel kosten moeilijk waarneembaar zijn, maar dat geldt waarschijnlijk ook voor de opbrengsten. 
De tweede ronde betreft het antwoord op de vraag: welke achtereenvolgende stappen moeten worden gezet als eenmaal voor een privatiseringsvariant is gekozen? Dan gaat het om de volgende stappen (zie tabel 3):

\section{Tabel 3. Stappenplan voor privatisering}

1. Om te beginnen moet de directe overheidsbemoeienis met de dagelijkse bedrijfsvoering en het operationele beheer van de betrokken organisatie worden losgelaten. Het operationele management moet vooral in handen van de leiding van de organisatie worden gelegd. Een eventueel prestatiecontract tussen opdrachtgevend ministerie en uitvoeringsinstantie dient te zijn toegespitst op prestatiemaatstaven, dus produkten en prijzen (en niet op procesmaatstaven want daar gaat de opdrachtgever niet meer over!). Zo'n prestatiecontract dient ook helder te zijn over prestaties en contra-prestaties.

2. De tweede stap betreft een fundamentele deregulering van de sector/bedrijfstak waarbinnen de betrokken organisatie werkzaam is, teneinde de organisatie ook de operationele handelingsvrijheid te geven om het afgesloten prestatiecontract te kunnen waarmaken. Deze deregulering zal veelal neerkomen op een andere vorm van regulering, ofwel herregulering: heldere spelregels vooraf, tussentijdse en periodieke controle en verantwoording achteraf.

3. Ten derde dient een vorm van 'werkbare concurrentie' tot stand te worden gebracht, hetzij binnen de publieke of non profit-sector in geval van (intern en externe) verzelfstandiging, hetzij binnen de marktsector waar naartoe de betrokken organisatie wordt geprivatiseerd. Verzelfstandiging van een overheidsmonopolie of verplaatsing daarvan naar de marktsector zonder enige vorm van concurrentie, leidt tot het monster van een marktmonopolie waarbij wij per saldo allemaal slechter af zijn. Een overheidsmonopolie wordt tenminste nog door de politiek gecontroleerd, al zijn voortdurende politieke interventies op hun beurt een slecht instrument om de macht van een overheidsmonopolie te beheersen. Een marktmonopolie wordt alleen door de aandeelhouders gecontroleerd en die hebben andere belangen.

4. De vierde stap betreft het invoeren van prijsmechanismen. Als echte prijssystemen om welke reden dan ook niet mogelijk zijn, dan resteren quasi-prijzen, maar iets is beter dan niets. Prijssignalen zijn beter in staat tot het sturen van produktie- en consumptiebeslissingen dan directe fysieke regulering van dat soort beslissingen, omdat zij de individuele keuzevrijheid intact laten en daarmee producenten en consumenten dwingen tot het nemen van beslissingen die in hun eigen ogen de beste zijn en niet in de ogen van de beleidsmakers. Prijssignalen die de echte schaarsverhoudingen niet adequaat weerspiegelen zullen in een open leerproces automatisch worden aangepast en anders is er de toezichthouder.

5. De vijfde stap houdt de oprichting van een specifieke toezichthouder in als die voor de betrokken markt al niet bestaat, dan wel het onderbrengen van de betrokken organisatie onder het algemene toezicht van de Nederlandse Mededingingsauthoriteit. De uiteindelijke keuze voor algemeen of specifiek toezicht hangt af van de bijzondere sectorkenmerken (en daarmee wellicht ook van de fase van de levenscyclus waarin de markt zich bevindt). Die toezichthouder dient ook een duidelijke takopdracht mee te krijgen en over de relevante expertise te beschikken. 
6. De zesde en laatste stap behelst de vormgeving van nieuwe besturingsrelaties binnen het horizontale beleidsnetwerk dat op deze manier wordt gecreëerd, waarin in elk geval de overheid als opdrachtgever, meerdere concurrerende uitvoerende instanties en toezichthouders daartussenin een positie innemen, en waartussen meer sprake is van tweezijdige transacties dan van eenzijdige regulering.

Alles goed en wel, maar kan zo'n abstract schema wel worden toegepast in de concrete beleidspraktijk? Laten wij daarom eens een snelle vingeroefening proberen met de NS. Hoewel dit geval eigenlijk thuis hoort in de categorie 'netwerksectoren' van Van Wijnbergen, leent het zich ook goed voor de algemene plan van aanpak van privatisering zoals hierboven gepresenteerd. In deze vingeroefening worden de vragen in twee ronden niet op de voet gevolgd, maar volsta ik met slechts een korte maar pregnante impressie.

\section{Een vingeroefening met de NS}

Dat het niet goed gaat met de NS(-Reizigers) is inmiddels iedereen wel duidelijk geworden, ook degenen die zelf nooit (meer) met de trein reizen. Waarom kan de NS niet wat de PTT, met name het postbedrijf, onder leiding van kundige managers wel keeft gekund: de draai naar de klant en de markt maken? Dat komt door de noodlottige samenloop van de historische erfenis van de NS aan de ene kant en het privatiseringsmoeras waarin het bedrijf is vastgelopen aan de andere kant.

\subsection{De hypotheek van het verleden}

Eerst maar een stukje geschiedenis. Tot ver na de Tweede Wereldoorlog vormde de NS net als de PTT een gesloten bedrijf van vooral techneuten. De werknemers waren trots op hun bedrijf (je werkte bij Pa Spoor) en dat generaties lang. Dat bedrijf was als een militaire kazerne georganiseerd, met een hiërarchische organisatiestructuur en bijbehorende afhankelijkheidscultuur, een interne oriëntatie en weinig klantgerichtheid. Bovendien was de afstand tussen werkvloer (machinisten en conducteurs) en het management (HGB, ofwel de 'Inktpot' in Utrecht) levensgroot. Maar dat gaf niet want in de dagelijkse praktijk was het vrijbuitende personeel 'baas op eigen trein'. Het gaat eigenlijk al in de jaren zestig voor de eerste keer fout, als de automobiliteitsrevolutie bij iedereen de gedachte doet post vatten, dat openbaar vervoer een achterhaalde zaak is en dat het met de NS gauw zal zijn gedaan. Er wordt niet meer geï nvesteerd, niet in vernieuwing en niet eens meer in vervanging. De gevolgen worden zichtbaar na de twee oliecrises in de jaren zeventig. Dat betekent nieuwe kansen voor het Openbaar Vervoer, maar de NS kan de nieuwe vraag niet opvangen en kan zelfs de bestaande vraag niet vasthouden. Alles verkeert in deplorabele staat: onderkomen infrastructuur, achterstallig onderhoud, ouderwets management, achterhaalde arbeidsverhoudingen.

Dan moet opeens alles tegelijk en in veel te korte tijd: versneld inlopen van achterstallig onderhoud, enorme uitbreiding van de infrastructuur, modernisering van de arbeidsverhoudingen en als klap op de vuurpijl privatisering van de eigen bedrijfsorganisatie. Dat moest dus wel fout lopen en dat deed het ook, en wel vooral op het laatste onderdeel, de privatisering van de NS. De Commissie-Wijfels heeft geadviseerd over de gewenste modernisering van de economische structuur van de NS, met name de opsplitsing van het bedrijf in afzonderlijke organisaties, maar trok zeer zeker niet de vergaande conclusie van complete privatisering. In de euforie van marktwerking en vermarkting van alles en nog wat in de publieke sector trok het eerste Paarse kabinet die conclusie wel en Paars-II weigert daarop terug te komen. In het geval van de NS is 
volledige privatisering niet goed doorgedacht en werkt zelfs averechts, omdat een aantal andere zaken niet of niet goed is geregeld. Dat komt omdat de economische privatiseringstheorie niet als consistente richtsnoer voor het privatiseringsbeleid wordt gebruikt. Die theorie wordt voor zover voorhanden gebrekkig toegepast op de NS.

\subsection{Gebrekkige privatiseringsaanpak}

Privatisering heeft alleen zin als er overheidsfalen door wordt opgelost en er zeker geen nieuw marktfalen door wordt veroorzaakt. Als van een overheidsmonopolie zomaar een marktmonopolie wordt gemaakt, zijn wij nog verder van huis. Privatisering is bovendien een proces dat in een logische volgorde moet worden afgewerkt, zo hebben wij vastgesteld. Laat ik uit de bovenstaande stappenreeks er vier uitlichten. De eerste stap is het ongedaan maken van de verticale integratie van de spoorweginfrastructuur en het gebruik ervan in één bedrijf, de NS. Beide moeten uit elkaar worden gehaald en in twee verschillende bedrijven worden ondergebracht. De tweede stap is substantiële deregulering van wet- en regelgeving in de betrokken sector. Er moet met name een einde worden gemaakt aan de directe overheidsbemoeienis met de bedrijfsvoering. De derde stap is het tot stand brengen van voldoende concurrentie en marktwerking. De overheidsbemoeienis moet worden overgenomen door de tucht van de markt. Daarbij horen ook een stevige toezichthouder en een nieuwe besturingsfilosofie. Dan pas komt de vierde en laatste stap: het verplaatsen van het overheidsbedrijf naar de marktsector.

Passen wij dit vereenvoudigde schema toe op de privatisering van de NS, dan wordt meteen duidelijk wat er is mis gegaan. Het opsplitsen van het bedrijf in aparte onderdelen (infrastructuur, capaciteitstoedeling en dienstregeling, reizigersbedrijf, goederenbedrijf, onderhoud) die met elkaar pseudo-marktrelaties moeten aangaan, is onvoldoende uitgekristalliseerd in nieuwe verhoudingen. Zo zijn al die nieuwe bedrijven zelf nog steeds monopolisten, die geen kant uit kunnen naar andere leveranciers of klanten. Bovendien zijn infrastructuur en gebruik nog onvoldoende uit elkaar gehaald. Directe bemoeienis met de bedrijfsvoering heeft de overheid dan wel losgelaten, maar zodra er iets mis gaat kan de politiek het niet laten. Dan roept iedereen in het parlement moord en brand en vraagt de minister om in te grijpen. Het verlengde prestatiecontract tussen NS-Reizigers en de minister is zelf een juridisch gedrocht van meer dan 100 pagina's, waarin volgens de beste stalinistische tradities alles wordt dichtgetimmerd en het bedrijf geen enkele vrijheid van bedrijfsvoering wordt gelaten. Het prestatiecontract beperkt zich dus niet tot de produkten, maar bemoeit zich ten onrechte ook en vooral met het productieproces.

Ook over marktwerking is niet goed nagedacht. Concurrentie kan in dit geval op twee manieren, zo hebben wij gezien: om het spoor door het netwerk op te splitsen in aparte baanvakken die elk door een ander bedrijf worden bereden op basis van een tijdelijke concessie, of op het spoor, door het hele netwerk door meerdere maatschappijen tegelijk te laten berijden. In beide gevallen gaan echter de schaalvoordelen van een natuurlijk monopolie verloren. Er zijn geen dalende kosten meer maar stijgende kosten, terugverdienperiodes van investeringen zijn te kort en er ontstaan dienstregelings- en dus aansluitings- en overstapproblemen. Bovendien wordt soms voor het één, concurrentie om het spoor, gekozen, en worden dus de Hoge Snelheidslijn, maar ook Noordnet en Syntus (in de Achterhoek) van de NS afgesplitst. Dan weer voor het ander, concurrentie op het spoor, en wordt dus Lovers toegelaten op een toch al te druk bereden baanvak Amsterdam-Zandvoort. Beide tegelijk kan echter niet en er wordt niet consequent gekozen voor doordachte uitwerking van één variant. Voorts is er onduidelijkheid over de relevante toezichthouder (wie is dat dan?) en over de besturingsfilosofie (wie kan waarop worden aangesproken?). Tenslotte: de voorgenomen beursgang van NS-Reizigers is niet de eerste maar de laatste stap van het privatiseringstraject. Zonder concurrentie en marktwerking op of om het spoor maakt dat de zaak alleen maar erger, niet beter, want een marktmonopolie wordt behalve door de aandeelhouders door niemand meer gecontroleerd. 


\subsection{Wat moet er nu worden gedaan?}

Welke beleidsaanbevelingen kunnen op grond van deze snelle vingeroefening worden geformuleerd? De eerste conclusie ligt voor de hand: de directie staat voor een bijna onmogelijke opgave. Vervanging van het management lost de problemen niet op, want die blijven dezelfde. Geen wonder ook dat het personeel en de bonden onhandelbaar zijn, want zij zien het bedrijf onder hun ogen kapot gaan. Het is nu alle hens aan dek. De verschillende problemen moet uit elkaar worden gehaald en stuk voor stuk worden aangepakt.

Eerst moet er rust aan het privatiseringsfront komen, dus weg van directe politiek bemoeienis. De nieuwe rol van de overheid als procesarchitect komt pas in een later stadium aan de orde. Dan een strategische discussie over de toekomst van NS-Reizigers, niet alleen intern binnen de NS maar ook extern tussen de NS en alle partijen die een maatschappelijk belang bij de NS hebben (de 'stake holders'), dit in combinatie met het althans voorlopig afblazen van de beursgang. Verder moet de interne bedrijfsvoering op orde worden gebracht (de beruchte 'procesvereenvoudiging') en moeten de diverse investeringen beter worden geregisseerd. Daarbij dient de NS de reële mogelijkheid van toekomstige concurrentie op het spoor of om het spoor als uitgangspunt en randvoorwaarde te hanteren. Externe omgevingsstabiliteit en interne bedrijfsherordening maken tenslotte ook ruimte vrij voor modernisering van de arbeidsverhoudingen.

Alleen op deze manier kan de gordiaanse knoop waarin NS-Reizigers verstrikt is geraakt, worden doorgehakt. Wordt het anders gedaan, dan loopt het bedrijf een groot risico inderdaad ten onder te gaan. Eén ding is zeker: dan komt er nooit meer zo'n mooi bedrijf terug, dat heeft de internationale privatiseringsgeschiedenis ons inmiddels wel geleerd.

\section{Bij wijze van conclusie}

De economische theorie levert dus wel degelijk een analytische gereedschapskist op om zin en onzin in het debat over overheid versus markt van elkaar te onderscheiden. Op basis daarvan kan ook een (meer procedureel en procesmatig) plan van aanpak van privatisering worden ontwikkeld. Daarmee kan de gang van zaken van een concreet privatiseringstraject worden geanalyseerd (zowel feitelijk, dus ex post, als voorgenomen, dus ex ante). Bovendien kunnen zo zwakke plekken, leemten en lacunes en foute beslissingen in het traject worden opgespoord. Op basis daarvan kunnen weer concrete beleidsaanbevelingen worden geformuleerd.

Markt en overheid zijn institutionele arrangementen om maatschappelijke problemen op te lossen, niet minder maar zeker ook niet meer. Hier ligt nog een heel onderzoeksterrein braak voor de kritische en onafhankelijke universitaire (economische) wetenschap. Dat terrein moet niet worden overgelaten aan al te snelle consultants en organisatieadviesbureaus, want de praktijk (mijn kroongetuige is de Betuwelijn, zie het rapport van de Algemene Rekenkamer, 2000) leert dat die er nogal eens een wetenschappelijk potje van maken, afhankelijk als zij zijn van hun politieke opdrachtgevers. 


\section{Gebruikte literatuur}

J. Alberts en K. Berkhout, Een blauwdruk voor de privatisering, in NRC-Handelsblad, 23 september 1999.

Algemene Rekenkamer, Beleidsinformatie Betuweroute, Den Haag juni 2000.

Th.W.A. Camps, Bij het scheiden van de markt. Symbiose en antibiose in publiek-private relaties, oratie Katholieke Universiteit Brabant 15 juni 2001, Assen 2001.

S. Connolly and A. Munro, Economics of the Public Sector, London etc. 1999.

H. Daudt en E. van der Wolk (red.), Bedreigde Democratie?, Assen 1978.

J. van den Doel en B.C.J. van Velthoven, Democratie en Welvaartstheorie, (vierde druk), Alphen aan den Rijn 1998.

P. Hennipman, Economisch motief en economisch principe, Amsterdam 1945.

P. Kalma, De aanbidding van Koning Klant, in De Volkskrant, 23 juni 2001 (2001a).

P. Kalma, Generaal Kalshoven vecht de vorige oorlog uit, in De Volkskrant, 4 juli 2001 (2001b).

F. Kalshoven, Paul Kalma wil de consumentenmacht niet snappen, in De Volkskrant, Het Spel en de Knikkers, 30 juni 2001 (2001a).

F. Kalshoven, Paul Kalma, het cocktailtrio en de linkse politiek, in De Volkskrant, Het Spel en de Knikkers, 7 juli 2001 (2001b).

A. Klamer e.a., De beschaving moet gered worden, in NRC Handelsblad, 1 mei 2001.

J. LeGrandt and W. Bartlett, Quasi-Markets and Social Policy, Basingstoke and London 1993.

J.G.A. van Mierlo, De wereld gaat aan beleid ten onder... Over beleidsfalen in de publieke sector en wat daar aan te doen, oratie Universiteit Maastricht, 29 juni 2000, Maastricht 2000.

E.J. Mishan, The Costs of Economic Growth, London 1968.

J.E. Stiglitz, Economics of the Public Sector, (third edition), Boston etc. 2000.

S.P.M. de Waal, Nieuwe strategieën voor het publieke domein. Maatschappelijk ondernemen in de praktijk, Alphen aan den Rijn 2000.

K. Walsh, Public Services and Market Mechanisms. Competition, Contracting and the New Public Management, Basingstoke and London 1995.

Wetenschappelijke Raad voor het Regeringsbeleid, Het borgen van publiek belang, Rapporten aan de Regering 56, Den Haag 2000.

Ch. Wolfe, Markets or Governments. Choosing between Imperfect Alternatives, second revised edition, Cambridge 1993.

D.J. Wolfson, Verwarring van doeleinden en instrumenten bedreigt de democratie, in Daudt en Van der Wolk, Assen 1978.

D.J. Wolfson, Publieke Sector en Economische Orde, Groningen 1988. 
D.J. Wolfson, Theorie en Toepassingen van de Economische Politiek, Bussum 2001.

S. van Wijnbergen, De WRR snapt niets van privatisering, in NRC Handelsblad, 3 juni 2000. 